\title{
The Process and the Personal Cost of Genocide
}

\author{
Nikki Marczak and Kirril Shields
}

It is with a mixture of sadness and appreciation that we include, in this edition of Genocide Perspectives, the final published text of Professor Colin Tatz. The father of Australian genocide studies, and Founding Director of the Australian Institute for Holocaust and Genocide Studies (AIHGS), Professor Tatz passed away on 19 November 2019. In the wake of his death he has been honoured by individuals he inspired, organisations he worked with, and communities whose experiences he shed light on and for whom he advocated tirelessly throughout his life. He has been hailed as a 'doyen of genocide studies academics,' ${ }^{1}$ celebrated on $\mathrm{ABC}$ and SBS radio, by Armenian and Jewish communal representatives, and the universities at which he taught. ${ }^{2}$ His dedication to challenging racism has been at the forefront of tributes, and his courage and rebellious streak

1 'Colin Tatz Has Passed Away at 85', J-Wire, November 19, 2019, https:// www.jwire.com.au/colin-tatz-has-passed-away-at-85/.

2 Phillip Adams, 'Remembering Colin Tatz', Late Night Live, ABC Radio, November 20, 2019, https://www.abc.net.au/radionational/programs /latenightlive/remembering-professor-colin-tatz/11722570; 'Vale Emeritus Professor Colin Tatz', November 22, 2019, https://politicsir.cass.anu.edu.au /vale-emeritus-professor-colin-tatz.

How to cite this book chapter:

Marczak, N. and Shields, K. 2020. The Process and the Personal Cost of Genocide. In: Marczak, N. and Shields, K. (eds.) Genocide Perspectives VI: The Process and the Personal Cost of Genocide. Pp. 1-6. Sydney: UTS ePRESS. DOI: https://doi .org/10.5130/aaf.a. License: CC BY-NC-ND. 
admired by all those who knew him. ${ }^{3}$ To us and the other members of AIHGS, he was Colin-our mentor and friend, and we will always remember him.

Colin adapted some of his 2019 book, The Sealed Box of Suicide: The Contexts of Self-Death, for an essay in this collection, and it is perhaps fitting that his last topic of writing relates to existential questions around life and death, personal choices, and the legacy of trauma, grief, and mourning.

Professor Tatz was never one to shy away from unorthodox and original theses, but his views were always informed by decades of practical, collaborative work with Indigenous communities. In his paper 'Genocide and Suicide, Tatz draws connections between the two. Sometimes they are co-existent, as noted through the Holocaust and Armenian cases, but in the main he focuses on Aboriginal communities in Australia, arguing that the high rates of suicides are not the result of mental illness, nor a phenomenon that can be medicalised or treated within a 'mental health' framework. Rather, he positions suicide as arising from centuries of colonisation, theft of land, and destruction of identity, families ripped apart under government policy, institutional sexual abuse, the Western legacy of drug and alcohol abuse, and from a cycle of socio-economic disadvantage. It is the consequence of decades of trauma and exacerbated by a sequence of paternalistic government policy, Tatz argues, that denies Aboriginal and Torres Strait Islander peoples' self-determination. But Tatz goes further, asserting that in this context, suicide may be a rational choice, to escape one's existence in the absence of hope. Low life expectancy in Aboriginal communities means that funerals are constantly being held; children are exposed to death regularly and from an early age. Sadness and grief are not the same as mental illness, but they are so intrinsic to many Aboriginal lives that suicide must be understood as a response and a valid choice.

Tatz's contribution sets the tone of Genocide Perspectives VI as a volume that offers new insight into the past, reinvigorating debate and providing scholarly contemplation on the 'crime of crimes', genocide. In this edition, among other topics, contributors explore the causal factors in the emergence of genocide, and reveal the impact of the Holocaust on individuals and families. Aspects of Indigenous Australian experiences are discussed, so too the persecution of particular groups by the Nazis. The legacy of the Armenian Genocide is explored through the 'long shadows' of the Ottoman era that are currently influencing atrocities in the Middle East, while the role of global governments in halting or fuelling the process of genocide is a key focus.

Once again, in the spirit of AIHGS, we have chosen to emphasise Australian scholarship, providing a platform for both established scholars and emerging ones. Australian scholars are at the forefront of genocide studies and have their own historical perspective living in a post-colonial, post-genocidal nation.

${ }^{3}$ Nikki Marczak and Meher Grigorian, 'A Rebel with a Cause and a Teacher with Heart', Plus61J, November 25, 2019, https://plus61j.net.au/plus61j -voices/rebel-cause-teacher-heart/. 
Authors represented here, we believe, portray the diverse areas of study and research undertaken in the country, and their contributions are valuable to the expanding literature on genocide.

Genocide Perspectives VI begins with a densely analytical, evidence-based thesis on how political leadership can either fuel the fires that lead to mass atrocity or, alternatively, divert a nation away from conflict and violence. Alex J Bellamy and Stephen McLoughlin are respected experts on the United Nations endorsed concept of the Responsibility to Protect, which holds that states have a responsibility to protect peoples within their borders from atrocity crimes, and that where a state manifestly fails to do so, the international community has a responsibility to intervene. In this essay, Bellamy and McLoughlin explore the role of political leaders in driving the course of a country either towards violence, or diffusing the conditions that could lead to it. Although much research has been undertaken on the influence of leaders such as Adolf Hitler and Josef Stalin in pushing countries, indeed continents towards genocide, little is understood about the strategies leaders can effectively use to pull back from the brink. Providing a plethora of examples, from Kenya to postApartheid South Africa, Tunisia to Macedonia, Bellamy and McLoughlin show how decision making by leaders, even in nations that have the preconditions for atrocity crimes, can prevent mass violence. The stark comparison with recent examples of protracted conflict marred by attacks against civilians, such as the case of Syria, is extremely impactful. Their argument that leadership plays an important role in atrocity prevention must prove to be a cornerstone of atrocity prevention scholarship.

Similarly, Melanie O’Brien looks at genocide as a process rather than a oneoff event, showing how violation of the right to freedom of religion manifested in a range of case studies. O'Brien examines the tactic of genocidal regimes of breaching the human right of freedom of religion in order to destroy the victim group, through the lens of the Holocaust, the Cambodian Genocide and the Armenian Genocide. Even when the target group is not defined purely as a religious group, O'Brien argues, the violation of freedom of religion contributes to the genocide. With a strong foundation in human rights law, this essay shows the journey of a gradual violation of rights towards mass atrocity crimes.

In the third essay, Katharine Gelber gives us a highly personal view of the sorts of rights violations O'Brien describes. As a child of a Holocaust survivor who never spoke of his experiences, Gelber grew up with minimal insight into her father's past, and it was only after he died in 2017 that she 'discovered a trove of objects, artefacts of a life I knew almost nothing about but which he had had in his possession for decades. Gelber spoke at The University of Queensland's Yom HaShoah, or Holocaust Memorial Day event in 2019, and presented her findings from a two year research journey that has culminated in her donating her father's belongings to the Sydney Jewish Museum as The Gelber/Altschul Collection. Just as important, her journey has shed light on aspects of her family history that have left both visible and hidden scars 
-intergenerational effects that are common to many children of survivors, even (perhaps especially) when they were told nothing of their parents' trauma.

The impact of Nazi persecution is told from a very distinct but equally personal perspective by Amanda Tink, who frames her essay with the continual consciousness that as a person with a disability, she would have suffered a terrible fate had she been born in the Nazi era. Tink writes, 'As with all genocides, its roots are in our language, and language around disability remains resolutely dehumanising. Tink explores the Nazi genocide of people with mental and physical disabilities through Australian author Les Murray's text, Fredy Neptune. Murray was mildly autistic and he draws on his own experiences as well as those of his autistic son to convey prejudice and violence against people with disabilities. These are told through the eyes of two characters-Fredy, also autistic, who develops a physical and emotional reaction (superhuman strength and loss of pain) after witnessing a brutal act of murder during the Armenian Genocide, and Hans, an intellectually impaired young man whom Fredy rescues from Germany in 1933. Once again, the nature of genocide as an evolving and escalating process of prejudice, discrimination, language, violation of rights, and finally violence, is emphasised in Tink's paper, first with the ideology of eugenics permeating language around those with disabilities, deeming them as inferior and unworthy of life, and then, with their rights gradually taken away over time, eventually even their right to life.

The role of perpetrators in the Nazi 'euthanasia' programme discussed in Tink's paper is explored in detail in Linda Shields and Susan Benedict's essay on the role of nurses in Nazi Germany. Despite being one of the 'caring professions', nurses participated, with varying degrees of willingness, in the murder of disabled people - a category that the Nazis did not hesitate to expand to take in more and more victims. Shields and Benedict provide background about the propaganda of eugenics that was designed to convince those working in the Nazi system that their actions were not only legally required but morally right, and outline the processes undertaken in hospitals to determine which individuals were no longer 'worthy of life.' The question of how medical professionals could starve children, force feed people lethal doses of drugs, or leave victims outside in the cold to die remains unanswered, but Shields and Benedict's essay provides insight into the often banal and sometimes ideologically driven motivations for perpetrators of genocide.

Complementing Tatz's piece by exploring the exploitation and trauma of Indigenous Australian communities from a different point of view, is Jacob G. Warren's essay on Maralinga and nuclear colonialism. Warren describes the pain and 'violent realities' of seeing Maralinga, this 'invisibly scarred and toxic region only two hours north of the much-used Eyre Highway'. Just as Tink analysed genocide through literature, so too does Warren examine Indigenous genocide (the destruction of the peoples, identity, and land) via visual art. Warren describes the sand-covered painting Maralinga by Jonathan Kumintjara Brown and the five-metre tall installation Thunder Raining Poison by Yhonnie 
Scarce, drawing connections with the image of the desert as 'void', terra nullius, the notion that the land was uninhabited, and environmental injustice a form of slow violence. Like many of the other essays in this collection, Warren grapples with the understanding of genocide as a slow gradual process but still evident today in the artworks depicting the nuclear destruction of Maralinga.

Another site of historical violence against Indigenous Australians is Myall Creek, where a massacre took place in 1838 of 28 men, women and children of the Kamilaroi nation. Each year that event is commemorated, and it is well known because it was one of the only massacres of Aboriginal people that resulted in prosecution against the perpetrators. Mark Tedeschi QC, who wrote a book on the event titled Murder at Myall Creek, gave a speech at the 2017 commemoration that he has generously allowed us to publish here. Tedeschi contemplates the significance of the unique prosecution of convicts for the murder of Aboriginal people and highlights the role of those individuals who refused to remain silent in the face of this horrendous crime. He points out the similarities between the case and modern war crimes trials, although war crimes as a concept had not been invented. Indeed, Tedeschi asserts that the 'actions of the Myall Creek murderers were war crimes and part of a deliberate, state-sanctioned genocide of the Aboriginal people that today would be punishable by the rules of international criminal law.

Australian history, and the legacy of genocide, are two topics explored by Caroline Schneider and Hans-Lukas Kieser in their essay based on the 2018 exhibition in Canberra, 'Long Shadows-The Great War, Australia and the Middle East'. The exhibition and the essay look at the connections between the ANZAC experience and the Armenian Genocide, drawing on experiences of Australian soldiers who witnessed genocidal crimes as well as humanitarian efforts by Australian organisations to assist Armenian victims, all the while asking why the Armenian Genocide does not have a more prominent place in Australian and ANZAC history. The authors draw yet another important connection, between the persecution of the Ottoman era against ethnic and religious minorities, and the echoes, or 'long shadows', in the Middle East today, most clearly seen in the 2014 genocide of the Yazidis in Northern Iraq. The parallels between the two cases must compel us to ask why we still have not learnt from history, taking us back to Bellamy and McLoughlin's analysis of leadership and atrocity prevention.

Schneider and Kieser mention the transgenerational impact of the Armenian Genocide on the Armenian community and this issue is analysed in depth in the final essay of the collection, "It's Happening Again": Genocide, Denial, Exile and Trauma', by Armen Gakavian. First examining how survivors and their descendants have responded to the ongoing trauma of the genocide over the past three decades, Gakavian goes on to identify two newer responses. The first-engagement with Turkish government, civil society and individuals has an 'outward, positive focus' whereby diasporan Armenians are willing to engage with Turkish peers in the more neutral environments of North 
America, Europe, and Australia. Likewise, there has been a shift among some segments of the Turkish community that have proven willing to honestly confront their nation's history. The second more recent response, Gakavian argues, is one of fear among Armenian communities that the genocide is happening again'. Gakavian looks at responses to the 1988 earthquake, the conflict in Nagorno-Karabakh, and the recent conflicts in the Middle East especially in Syria, analysing how Armenians view such events through the lens of their unresolved trauma and Turkish denial.

We are very privileged to have co-edited this timely and original contribution to the Genocide Perspectives Series and to genocide studies literature more broadly. We thank the AIHGS for the honour, and all the contributors for their hard work. 